\title{
Antidiabetic Effects of Aqueous Leaf Extracts of Acacia nilotica in Alloxan Induced Diabetic Mice
}

\author{
Mwangi J Mukundi ${ }^{1,2 *}$, Ngugi M Piero' ${ }^{1}$, Njagi EN Mwaniki ${ }^{1}$, Njagi J Murugi ${ }^{3}$, Agyirifo S Daniel ${ }^{1,4}$, Gathumbi K Peter ${ }^{5}$ and Muchugi N Alice ${ }^{6}$ \\ ${ }^{1}$ Department of Biochemistry and Biotechnology, School of Pure and Applied Sciences, Kenyatta University, P.O. Box 43844-00100, Nairobi, Kenya \\ ${ }^{2}$ Department of Science, Narok Teachers Training College, P.O Box 709, Narok, Kenya \\ ${ }^{3}$ Department of Environmental and Population Health, School of Public Health, Kenyatta University, P.O. Box 43844-00100, Nairobi, Kenya \\ ${ }^{4}$ Department of Molecular Biology and Biotechnology, University of Cape Coast, Ghana \\ ${ }^{5}$ Department of Veterinary Pathology, Microbiology and Parasitology, College of Agriculture and Veterinary Sciences, University of Nairobi, P.O. Box 29053, Nairobi, \\ Kenya \\ ${ }^{6}$ Genetic Resources Unit, World Agroforestry Centre. P.O. Box 30677-00100, Nairobi, Kenya
}

\begin{abstract}
Diabetes is increasingly affecting a growing number of patients and seriously reducing their quality of life. Use of conventional drugs in diabetes management is expensive, thus, unaffordable to most patients. Furthermore most of these conventional drugs are associated with undesirable side effects. Incorporation of herbal medicine into conventional healthcare system may significantly improve the overall healthcare system. Evaluation of efficacy and safety by scientific method is necessary to validate herbal medicine utilization, in most cases even where efficacy of the plants has been established the standard dosage required to bring about healing is not clear. This study was designed to designed to evaluate the antidiabetic potential of aqueous leaf extracts of Acacia nilotica in alloxan induced diabetic mice. As the results show, the aqueous leaf extracts of $A$. nilotica showed antidiabetic activity. The intraperitoneal route of herbal extract administration was found to be more effective than the oral route. Further, qualitative and quantitative phytochemical screening of aqueous leaf extracts of $A$. nilotica indicated the presence of phenols, alkaloids, flavonoids, tannins and saponins. However, cardiac glycosides and phylobatanins were not detected.
\end{abstract}

Keywords: Diabetes mellitus; Aqueous extracts; Antidiabetic activity; Phytochemicals

\section{Introduction}

Diabetic mellitus (DM) is ranked seventh among the leading causes of death and third when its fatal complications are taken into account [1]. Within the human body the pancreas controls blood glucose by producing and releasing the hormones insulin and glucagon, which stabilize blood glucose within the physiological range of $70-120 \mathrm{mg} /$ dl. DM is characterized by a dysfunction of the pancreas, often in combination with reduced insulin sensitivity [2]. Hyperglycemia and defective metabolism of glucose and lipids is also observed, this leads to an elevation of blood glucose due to relative or absolute deficiency of insulin [2].

Orthodox treatment of diabetes mellitus includes modification of lifestyle, such as diet and exercise and the use of insulin or oral hypoglycemic drugs. Pharmacologic agents target increased insulin secretion, decreased hepatic glucose production and increased sensitivity to insulin [3]. Use of insulin or oral hypoglycemic agents is associated with drawbacks such as as ineffectiveness on oral administration, short shelf life, requirement of constant refrigeration and in the event of excess dosage fatal hypoglycemia. The use of oral hypoglycemic drugs like sulfonylureas and biguanides is also associated with tendency to gain weight [3]. Traditional medicines (TM), are widely used in Africa, including diabetes management because of the high cost associated with orthodox medicines, inadequate health facilities and health care professionals, coupled with inadequate training of health workers [4].

For many patients, traditional medicine appears to offer more gentle means of managing such diseases when allopathic medicines fail to work or to patients who cannot afford them [5]. Due to inadequate knowledge of the contents of medicinal plants, herbal medicines are not often regulated and the lack of information on the pharmacological toxicity of their compounds is a major concern [6].
Acacia nilotica is a shrub with an umbrella shaped crown with low branches, which are often scattered. It grows to a height of 3-5 metres, some of the documented uses include treatment of veneral diseases, by use of root or bark extract. Treatment of nausea, burns and wounds by use of chewed leaf or boiled bark, treatment of stomachache and diarrhoea, boiled leaf extract used for treatment of chest pain or pneumonia, gonorrhea, impotence and chest diseases, fever, malaria, headache, coughs, painful joints, backache, stomach ulcers among many other medicinal uses. The plant is also reported to have cultural uses among the Maasai such as performing certain rituals during circumcision [7].

Acacia nilotica is multipurpose nitrogen fixing tree legume that is widespread in Africa and Asia, and occurs in Australia. It is a complex species with nine subspecies, of which six are native to the African tropics and three others are native to the Indian subcontinent. It occurs from sea level to over $2000 \mathrm{~m}$ and can withstand extremes of temperature $\left(>50^{\circ} \mathrm{C}\right)$ and air dryness but is frost sensitive when young. It is considered as a very important economic plant since early times as a source of tannins, gums, timber, fuel, fodder and medicine [8]. Acacia nilotica can provide the nutrients and therapeutic ingredients to prevent, mitigate or treat many diseases or conditions. It also serves as a

*Corresponding author: Mwangi J Mukundi, Department of Science, Narok Teachers Training College, P.O Box 709, Narok, Kenya, Tel: 254721279 669; E-mail: johnmukundi1973@gmail.com

Received April 23, 2015; Accepted May 30, 2015; Published June 05, 2015

Citation: Mukundi MJ, Piero NM, Mwaniki NEN, Murugi NJ, Daniel AS, et al (2015) Antidiabetic Effects of Aqueous Leaf Extracts of Acacia nilotica in Alloxan Induced Diabetic Mice. J Diabetes Metab 6: 568. doi:10.4172/2155-6156.1000568

Copyright: (c) 2015 Mukundi MJ, et al. This is an open-access article distributed under the terms of the Creative Commons Attribution License, which permits unrestricted use, distribution, and reproduction in any medium, provided the original author and source are credited. 
source of polyphenols. However, pods and tender leaves are considered very beneficial in folk medicine to treat diabetes mellitus [9].

Acacia nilotica has been used traditionally for management of diabetes mellitus complications. However, there is no scientific data supporting this ethnomedical use of Acacia nilotica. It is against this background that this study was designed to evaluate the antidiabetic potential of aqueous leaf extracts of Acacia nilotica in alloxan induced diabetic mice.

\section{Materials and Methods}

\section{Collection and preparation of plant materials}

Stems barks of A. nilotica were collected from Narok County, Loita division in July 2012, Cross identification with vernacular names of the plants was done before validation by a qualified taxonomist at the East Africa herbarium, National Museums of Kenya (NMK). Voucher specimens were deposited at the NMK and voucher number assigned as JM02.

\section{Preparation of aqueous extracts}

The collected plant materials were chopped into small pieces, dried under shade at room temperature for four weeks, and then ground into fine powder by a mechanical grinder, followed by sieving through a 40 mesh sieve. The powders were packed in clean dry plastic air tight bags. One hundred grams (100 g) powder of each plant extract was later extracted in 1 liter of distilled water at $60^{\circ} \mathrm{C}$ in a metallic shaker for 6 hours. The extracts were decanted into clean dry conical flasks and then filtered through Whatman filter paper number 1 by use of a Buchner funnel at the biochemistry laboratory of Kenyatta University. The filtrates were stored in a refrigerater at $4^{\circ} \mathrm{C}$. Freeze drying was done in $200 \mathrm{ml}$ portions in a Modulyo freeze dryer (Edward England) for 48 hours and yield of each extract determined, freeze dryed materials were stored in a freezer at $-20^{\circ} \mathrm{C}$ until the time that they were used.

\section{Laboratory animals}

Healthy adult male Swiss albino mice, 3-5 weeks old and 20-30 g in weight were used in the study. The animals were allowed to acclimatize for a period of two weeks in the animal house at the department of Biochemistry and Biotechnology Kenyatta University prior to the study. The mice were housed in polypropylene cages, maintained under standard laboratory conditions of 12 hour light and dark sequence, at ambient temperature of $25 \pm 2^{\circ} \mathrm{C}$ and $35-60 \%$ humidity. The animals were fed with standard mice pellets obtained from Unga Feeds Limited, Kenya, and water ad libitum.

\section{Experimental design}

The following groups of mice were used for the experiments, group I, normal untreated mice was administered with $0.1 \mathrm{ml}$ physiological saline, group II diabetic untreated mice (the negative control) was administered with $0.1 \mathrm{ml}$ physiological saline, group III, alloxan induced diabetic control mice was administered with $0.06 \mathrm{mg}$ of glibenclamide (for oral based experiment) or insulin (for intraperitoneal based experiment) $3 \mathrm{mg} / \mathrm{kg}$ body weight (positive control group) in $0.1 \mathrm{ml}$ physiological saline, group $1 \mathrm{~V}$, (diabetic mice treated with $50 \mathrm{mg} / \mathrm{kg}$ body weight of plant extracts, Group V, (diabetic mice treated with $100 \mathrm{mg} / \mathrm{kg}$ body weight) of plant extract, group V1 (diabetic mice treated with $200 \mathrm{mg} / \mathrm{kg}$ body weight of plant extracts ), group V11 (diabetic mice treated with $300 \mathrm{mg} / \mathrm{kg}$ body weight of plant extract. The extracts were first dissolved in $0.1 \mathrm{ml}$ physiological saline, oral and intraperitoneal routes were used in separate groups as indicated above.

\section{Induction of hyperglycemia}

Diabetes was induced experimentally by administration of $10 \%$ alloxan-monohydrate (Sigma Chemicals, St. Louis, $\mathrm{OH}$ ). The animals were fasted for 8-12 hours, but allowed free access to water. A dose of $186.9 \mathrm{mg} / \mathrm{kg}$ body weight alloxan monohydrate was administered by intraperitoneal injection while still fresh, the dose was found to be most optimum in inducing diabetes in a separate study [10]. Forty eight hours after injection, blood glucose was determined by use of glucose analyzer model (On call plus-ACON LAB Inc-U.S.A) with glucometer strips, lot number 2014-09. Mice with blood glucose levels above 2000 $\mathrm{mg} / \mathrm{L}(>11.1 \mathrm{mmol} / \mathrm{L})$, were considered diabetic and suitable for use in the study.

\section{Blood sampling and in vivo hypoglycemic assays}

Blood sampling was done by sterilizing the tail with $10 \%$ alcohol and then nipping the tail at the start of the experiment and after 1 , 2, 3, 4, 12 and 24 hours. The blood glucose levels were determined as described in section 3.6.

\section{Qualitative phytochemical screening}

Tannins were determined as follows; $2 \mathrm{ml}$ of $5 \% \mathrm{FeCL}_{3}$ was added to $2 \mathrm{ml}$ aqueous extract of each sample. Yellow brown precipitate indicated presence of tannins [11]. Alkaloids were determined as follows; $1.5 \mathrm{ml}$ of $1 \% \mathrm{HCL}$ was added to $2 \mathrm{ml}$ methanolic filtrates of samples. The solution was heated and six drops of dragendroff reagent was added. Orange precipitate confirmed presence of alkaloids [11].

For saponins determination, aqueous extract of $2 \mathrm{~g}$ powder was made and subjected to frothing test. Frothing persistence indicated presence of saponins. Later the froth was mixed with few drops of olive oil. Formation of emulsion indicated presence of saponins [11]. For determination of flavonoids (shimodas test), $2 \mathrm{~g}$ material was extracted in $10 \mathrm{ml} \mathrm{H}_{2} \mathrm{O}$, few drops of $\mathrm{HCL}$ followed by $0.5 \mathrm{~g}$ of Zinc turnings were added. Tubes were boiled for a few minutes formation of pink colour indicated presence of flavonoids [12]

For phenolics determination, to $2 \mathrm{ml}$ of aqueous extract, $1 \mathrm{ml}$ of $1 \%$ ferric chloride solution were added. Blue colour indicated presence of phenols [11]. In determination of Phylobatannin, $10 \mathrm{ml}$ of aqueous extract of each plant sample was boiled with $1 \% \mathrm{HCl}$ acid in a test tube or conical flask. A deposition of a red precipitate indicated the presence of phlobatannins.

\section{Quantitative determination of phytochemicals}

Alkaloids : Two and a half grams ( $2.5 \mathrm{~g}$ ) of the powder was extracted using $100 \mathrm{ml}$ of $20 \%$ acetic acid in ethanol. The solution was covered for 4 hours, the filtrate was concentrated to $25 \mathrm{ml}$. Concentrated ammonium hydroxide was added stepwise to attain precipitation. The whole solution was kept as such so that precipitate will settle. Collected precipitate was washed with dilute ammonium hydroxide and finally filtered. Filtrate was discarded and pellet obtained was dried and weighed [11].

Saponins: Ten grams $(10 \mathrm{~g})$ of sample was mixed with $100 \mathrm{ml}$ of $20 \%$ aqueous ethanol. The mixture was kept for 4 hours on water bath shaker at $55^{\circ} \mathrm{C}$ filtrate was again extracted in same manner. The combined extract were concentrated to $40 \mathrm{ml}$ over water bath at $90^{\circ} \mathrm{C}$. Concentrate obtained was transferred into separating funnel and $10 \mathrm{ml}$ of diethyl ether was added to it. After shaking vigorously aqueous layer was recovered and ether layer was discarded. The process was repeated. To the aqueous layer $\mathrm{n}$-butanol was added. The whole mixture was 
washed in separating funnel twice with $10 \mathrm{ml} 5 \%$ of aqueous Nacl. Upper part was retained and heated in water bath until evaporation. Later it was dried in oven to a constant weight [11].

Phenolics: One gram $(1 \mathrm{~g})$ of sample powder was extracted with $80 \%$ ethanol. Filtrate obtained was evaporated to dryness and again redissolved in water. Different aliquots $(0.1-1 \mathrm{ml})$ were pippeted out and volume was made to $3 \mathrm{ml}$ by distilled water $0.5 \mathrm{ml}$ of Folins reagent followed by $2 \mathrm{ml} 20 \% \mathrm{Na}_{2} \mathrm{CO}_{3}$ solution was added. Tubes were vortexed, heated in boiling water for $1 \mathrm{~min}$ and finally cooled. Absorbance was measured at $650 \mathrm{~mm}$ against blank. A standard curve using different concentrations of $2 \mathrm{mg} \%$ catechol was prepared [11].

Tannins: Two grams $(2 \mathrm{~g})$ of plant powder from each sample was extracted thrice in $70 \%$ acetone. Samples were centrifuged and supernatant was collected. Different aliquots were prepared and final volume was made to $3 \mathrm{ml}$ by distilled water and vortexed, $1 \mathrm{ml}$ of $0.0016 \mathrm{M} \mathrm{K}_{3}\left(\mathrm{Fe}\left(\mathrm{CN}_{6}\right) 1 \mathrm{ml}\right.$ of $0.02 \mathrm{M} \mathrm{FeCL}_{3}$ in $0.1 \mathrm{M} \mathrm{HCL}$ were added. Tubes were shaken and then kept as such for 15 minutes, $5 \mathrm{ml}$ of stabilizer (3:1:1 ratio of water $\mathrm{H}_{3} \mathrm{PO}_{4}$ and $1 \%$ gum Arabic) was added and tubes were again revortexed. Absorbance was taken at $700 \mathrm{~nm}$, standard curve was plotted using different concentrations of $1.9 \mathrm{mg} \%$ gallic acid [11].

Flavonoids: Ten grams ( $10 \mathrm{~g})$ of the sample was extracted repeatedly with $100 \mathrm{ml}$ of $80 \%$ aqueous methanol at room temperature. The whole solution was filtered through whatman filter paper No 42. The filtrate was later transferred into a crucible and evaporated into dryness over a water bath and weighed to constant weight [12].

\section{Data analysis}

The data collected was entered into data base designed using Microsoft excel sheet. It was cleaned and organised into the SPSS software for statistical analysis. Data was expressed as Mean \pm standard deviation (SD). Differences between the means of the various groups of animals in the efficacy study was done using ANOVA and Post ANOVA statistical test, while the differences between the means of the two groups used in toxicity study was done using unpaired students $\mathrm{t}$-test. Level of significance for all the analysis was set at $\mathrm{P}<0.05$.

\section{Results}

\section{In vivo hypoglycemic activity of Acacia nilotica}

Aqueous stem bark extracts yielded a $0.56 \%$ light brown powder. Upon intraperitoneal administration, the aqueous stem bark extracts of A. nilotica decreased the blood glucose levels at all the four doses of 50,100, 200 and $300 \mathrm{mg} / \mathrm{kg}$ body weight (Table 1). This occurred in three phases, whereby in the first hour, the extract caused a steep decline in blood glucose levels, followed by a steady decline from the second to sixth hour. A gradual increase was then observed in the twenty fourth hour. However, the sugar levels were not reduced in a dose dependent manner. In the first hour, the extracts lowered blood glucose levels by $42 \%, 57 \%, 49 \%, 46 \%$ for $50,100,200$ and $300 \mathrm{mg} / \mathrm{kg}$ body weight doses, respectively, compared to insulin treated diabetic mice whose blood sugar levels were lowered by $66 \%$ within the first hour. By the third hour, all the four doses had lowered blood sugar levels by $61 \%, 66 \%, 70 \%$ and $70 \%$, respectively, compared to insulin treated diabetic mice whose sugar levels were lowered by $78 \%$ within the same hour (Figure 1).

Upon oral administration, the aqueous leaf extracts of $A$. nilotica also lowered blood glucose levels at all the four doses of 50, 100, 200 and $300 \mathrm{mg} / \mathrm{kg}$ body weight (Table 2), from the first hour to the sixth hour in a dose-independent manner. However, by the second hour, the extract had lowered the blood glucose levels by $30 \%, 27 \%$, $25 \%$, and $24 \%$ respectively for the four doses, compared to $34 \%$ for the conventional oral drug, glibenclamide (Figure 2). This is a doseindependent response. The reduction in blood glucose levels when compared to the negative control was statistically significant $(\mathrm{P} \leq 0.05)$ (Figure 2).

\section{Qualitative and quantitative phytochemical screening}

As Table 3 shows, Qualitative screening of aqueous extracts of Acacia nilotica indicated the presence of phenols, alkaloids, flavonoids, tannins, saponins, and phylobatannins and the absence of cardiac glycosides.

\section{Discussion}

In this study, the alloxan-induced diabetic mice had a three to four fold increase in blood glucose $(5 \mathrm{mg} / \mathrm{dl}$ to $20 \mathrm{mg} / \mathrm{dl}$ ) relative to the normal control rats. The alloxan destroys and reduces the pancreatic $\beta$-cell population via formation of reactive oxygen species like nitric oxide [13]. The aqueous leaf extract of Acacia nilotica showed blood glucose lowering effect when administered intra-peritonially and orally.

The glucose lowering effect of these plants was similar to that reported of other plants investigated earlier by researchers. The plant Memecylon malabaricum was found to possess antidiabetic activity, and the results were comparable to that of Gliclazide. The extract at $400 \mathrm{mg} / \mathrm{kg}$ p.o, showed a maximum reduction of raised blood glucose level as that of 100 and $200 \mathrm{mg} / \mathrm{kg}$. The results obtained indicated that the extract had a significant antidiabetic activity in rats [14]. In another study the aqueous extract of folk recipe (AFR) exhibited a dose-dependent hypoglycemic effect in the fasted-normal rabbits a 300 $\mathrm{mg} / \mathrm{kg}$ b.w. dose caused the most potent effect which was started with the administration of AFR at $1 \mathrm{~h}$ post-treatment and reached maximum

\begin{tabular}{|c|c|c|c|c|c|c|c|}
\hline \multirow{2}{*}{ Treatment } & \multicolumn{7}{|c|}{ Glucose Levels at Varying Times (mM) } \\
\hline & Ohr & $1 \mathrm{hr}$ & $2 \mathrm{hr}$ & $3 \mathrm{hr}$ & $4 \mathrm{hr}$ & $6 \mathrm{hr}$ & $24 \mathrm{hr}$ \\
\hline Control/Saline & $5.08 \pm 0.12$ & $5.26 \pm 0.17$ & $5.34 \pm 0.13$ & $5.34 \pm 0.15$ & $5.22 \pm 0.08$ & $5.32 \pm 0.83$ & $5.18 \pm 0.08$ \\
\hline Diabetic/Saline & $21.14 \pm 0.58$ & $22.46 \pm 0.50$ & $24.10 \pm 0.60$ & $25.18 \pm 0.44$ & $26.38 \pm 0.85$ & $27.64 \pm 1.05$ & $29.12 \pm 0.97$ \\
\hline Diabetic/Insulin & $22.54 \pm 0.56$ & $7.72 \pm 0.77^{\mathrm{a}}$ & $5.50 \pm 0.43^{a}$ & $4.92 \pm 0.19^{a}$ & $4.38 \pm 0.30^{\mathrm{a}}$ & $4.02 \pm 0.23^{a}$ & $6.26 \pm 0.79^{a}$ \\
\hline $50 \mathrm{mg} / \mathrm{kgbw}$ & $18.82 \pm 1.12$ & $10.86 \pm 1.94^{\mathrm{bc}}$ & $9.02 \pm 1.78^{\mathrm{bc}}$ & $7.42 \pm 1.47^{\mathrm{a}}$ & $5.92 \pm 1.04^{a}$ & $6.76 \pm 1.86^{\mathrm{a}}$ & $16.92 \pm 2.42^{\mathrm{bc}}$ \\
\hline 100 mg/kgbw & $15.04 \pm 0.94$ & $6.40 \pm 0.66^{\mathrm{a}}$ & $5.54 \pm 0.49^{a}$ & $5.08 \pm 0.44^{a}$ & $3.96 \pm 0.54^{\mathrm{a}}$ & $4.20 \pm 0.57^{\mathrm{a}}$ & $10.32 \pm 0.69^{b}$ \\
\hline $200 \mathrm{mg} / \mathrm{kgbw}$ & $17.28 \pm 1.95$ & $8.84 \pm 1.97^{\mathrm{ac}}$ & $6.38 \pm 1.15^{\mathrm{ac}}$ & $5.26 \pm 0.77^{a}$ & $4.96 \pm 0.68^{a}$ & $5.16 \pm 0.73^{a}$ & $12.06 \pm 2.20^{b}$ \\
\hline $300 \mathrm{mg} / \mathrm{kgbw}$ & $20.56 \pm 1.23$ & $11.04 \pm 2.84^{b c}$ & $8.46 \pm 2.11^{\mathrm{ac}}$ & $6.20 \pm 1.42^{a}$ & $6.32 \pm 1.40^{a}$ & $5.92 \pm 1.30^{a}$ & $13.84 \pm 1.66^{b}$ \\
\hline
\end{tabular}

Results are expressed as Means \pm SD for five animals per group. Values followed by the same superscript are not statistically different (P $\leq 0.05$; Analysed by ANOVA followed by Tukey's post hoc test).

Table 1: Effects intraperitoneally administered aqueous leaf extracts of Acacia nilotica on blood glucose levels in alloxan induced diabetic mice. 
Citation: Mukundi MJ, Piero NM, Mwaniki NEN, Murugi NJ, Daniel AS, et al. (2015) Antidiabetic Effects of Aqueous Leaf Extracts of Acacia nilotica in Alloxan Induced Diabetic Mice. J Diabetes Metab 6: 568. doi:10.4172/2155-6156.1000568

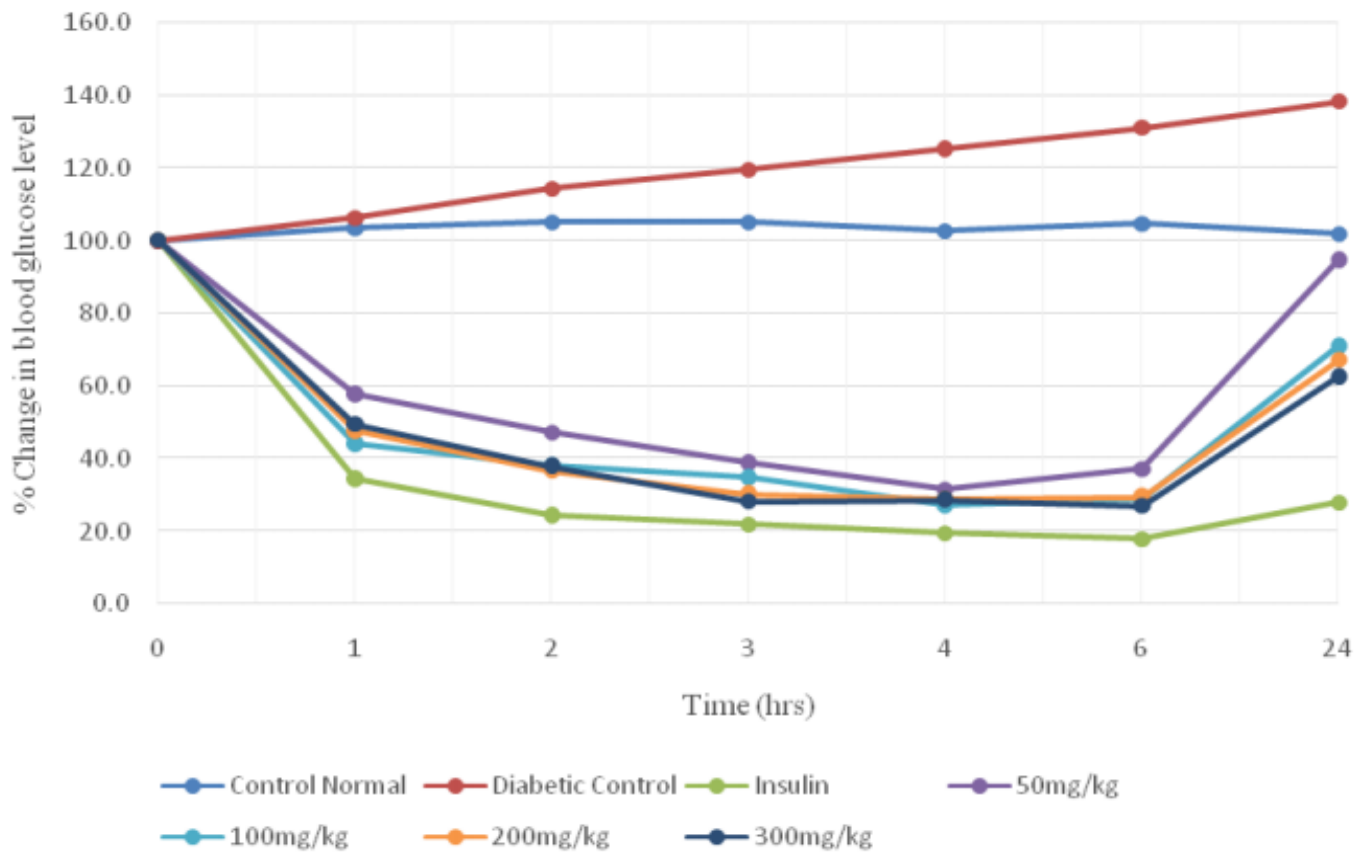

Figure 1: Mean percentage change in blood glucose levels of Acacia nilotica intraperitoneally administered in alloxan induced diabetic mice.

\begin{tabular}{|c|c|c|c|c|c|c|c|}
\hline \multirow{2}{*}{ Treatment } & \multicolumn{7}{|c|}{ Blood Glucose Levels at Varying Times (mM) } \\
\hline & Ohr & $1 \mathrm{hr}$ & $2 \mathrm{hr}$ & $3 \mathrm{hr}$ & $4 \mathrm{hr}$ & $6 \mathrm{hr}$ & $24 \mathrm{hr}$ \\
\hline Normal/ saline & $5.50 \pm 0.23$ & $5.24 \pm 0.15$ & $5.22 \pm 0.15$ & $5.20 \pm 0.16$ & $5.28 \pm 0.08$ & $5.32 \pm 0.08$ & $5.28 \pm 0.13$ \\
\hline Diabetic/saline & $17.41 \pm 1.61$ & $19.94 \pm 1.56$ & $20.82 \pm 1.63$ & $21.98 \pm 1.67$ & $23.00 \pm 1.68$ & $23.78 \pm 1.69$ & $24.64 \pm 1.76$ \\
\hline Diabetic/Glen & $22.38 \pm 0.81$ & $18.18 \pm 1.18^{\mathrm{a}}$ & $14.10 \pm 1.13^{a}$ & $11.24 \pm 0.78^{\mathrm{a}}$ & $8.00 \pm 0.56^{a}$ & $5.50 \pm 0.61^{\mathrm{a}}$ & $6.56 \pm 0.40^{\mathrm{a}}$ \\
\hline $50 \mathrm{mg} / \mathrm{kgbw}$ & $17.30 \pm 2.26$ & $14.42 \pm 2.62^{\mathrm{bc}}$ & $12.06 \pm 2.63^{\mathrm{ab}}$ & $9.78 \pm 2.08^{\mathrm{ab}}$ & $8.12 \pm 1.40^{\mathrm{ab}}$ & $6.10 \pm 0.44^{a}$ & $16.72 \pm 3.17^{b c}$ \\
\hline 100 mg/kgbw & $17.02 \pm 2.08$ & $14.40 \pm 2.09^{b c}$ & $12.50 \pm 1.73^{\mathrm{ab}}$ & $10.96 \pm 1.41^{\mathrm{ab}}$ & $9.48 \pm 0.93^{\mathrm{ab}}$ & $7.50 \pm 0.49^{a}$ & $16.32 \pm 2.14^{\mathrm{bc}}$ \\
\hline 200 mg/kgbw & $19.70 \pm 1.92$ & $16.90 \pm 2.52^{\mathrm{ac}}$ & $14.70 \pm 2.11^{\mathrm{ab}}$ & $12.66 \pm 1.92^{\mathrm{ab}}$ & $11.28 \pm 1.79^{b c}$ & $7.90 \pm 0.83^{a}$ & $15.98 \pm 1.79^{b c}$ \\
\hline 300 mg/kgbw & $19.68 \pm 2.31$ & $16.90 \pm 2.21^{\mathrm{ac}}$ & $15.04 \pm 1.80^{\mathrm{ab}}$ & $12.98 \pm 1.45^{\mathrm{abc}}$ & $9.44 \pm 0.91^{\mathrm{ab}}$ & $7.44 \pm 0.39^{a}$ & $14.60 \pm 1.52^{\mathrm{bc}}$ \\
\hline
\end{tabular}

Results are expressed as Means \pm SD for five animals per group. Values followed by the same superscript are not statistically different (P $\leq 0.05$; Analysed by ANOVA followed by Tukey's post hoc test).

Table 2: Effects of orally administered aqueous leaf extracts of Acacia nilotica on blood glucose levels in alloxan induced diabetic mice.

at 2-6 $\mathrm{h}$ intervals. A significant hypoglycemic effect in comparison to the fasted-control rabbits was observed at 24 and $48 \mathrm{~h}$ test points [15].

The possible mechanism through which the extracts might have brought about blood glucose lowering effect were either by increasing utilization of glucose or by direct stimulation of glucose uptake through increased insulin secretion [16]. It might also have been due to the extracts stimulating $B$ cells in islet of Langerhans, increased serum insulin and reduced blood sugar [17].

That aqueous leaf extracts of $A$. nilotica showed glucose lowering effect in intraperitoneal and oral routes, could be explained by easy movement of active principle across the cell membranes in the intraperitoneal cavity and gastro-intestinal mucosa.

The blood glucose lowering effect of these plant extracts may be attributed to the presence of phenols, flavonoids, alkaloids, tannins, phylobatanins, and saponins that have been associated with hypoglycemic activity [18]. Various researchers have demonstrated the antidiabetic activity of flavonoids, flavonoids isolated from leaf of ipomoea batatas, ameliorated blood glucose level and lipid parameters in alloxan induced diabetic mice at $50-150 \mathrm{mg} / \mathrm{kg}$ [19]. Flavonoid fraction from Pterocarpus marsupium has been shown to cause pancreatic beta cell regranulation. Epicatechin, its active principle, has been found to be insulinogenic thus enhancing insulin release and conversion of proinsulin to insulin in vitro [20]. Flavonoid glycosides such as strictinin, isostrictinin and pedunculagin are the effective constituents of Psidium guajava, which have been used in clinical treatment of diabetes due to improved sensitivity of insulin [21].

Previous researchers have demonstrated the hypoglycemic activity of triterpenoid glycosides [22,23]. Presence of saponins in this extract could also be responsible for the hypogycemic activity. For instance ginseng and its saponins have been shown to lower blood glucose in alloxan-treated, genetically diabetic, and normal mice [24].

Tannins can be classified into two broad group hydrolysable tannins and condensed tannins. Clinically all the forms of tannin may participate in managing glucose level in blood. Tannin stimulates the receptor cells to utilize carbohydrate [9].

\section{Conclusion}

From this study it can be concluded that the aqueous leaf extracts of $A$. nilotica showed antidiabetic activity. The intraperitoneal route of herbal extract administration was found to be more effective than 
Citation: Mukundi MJ, Piero NM, Mwaniki NEN, Murugi NJ, Daniel AS, et al. (2015) Antidiabetic Effects of Aqueous Leaf Extracts of Acacia nilotica in Alloxan Induced Diabetic Mice. J Diabetes Metab 6: 568. doi:10.4172/2155-6156.1000568

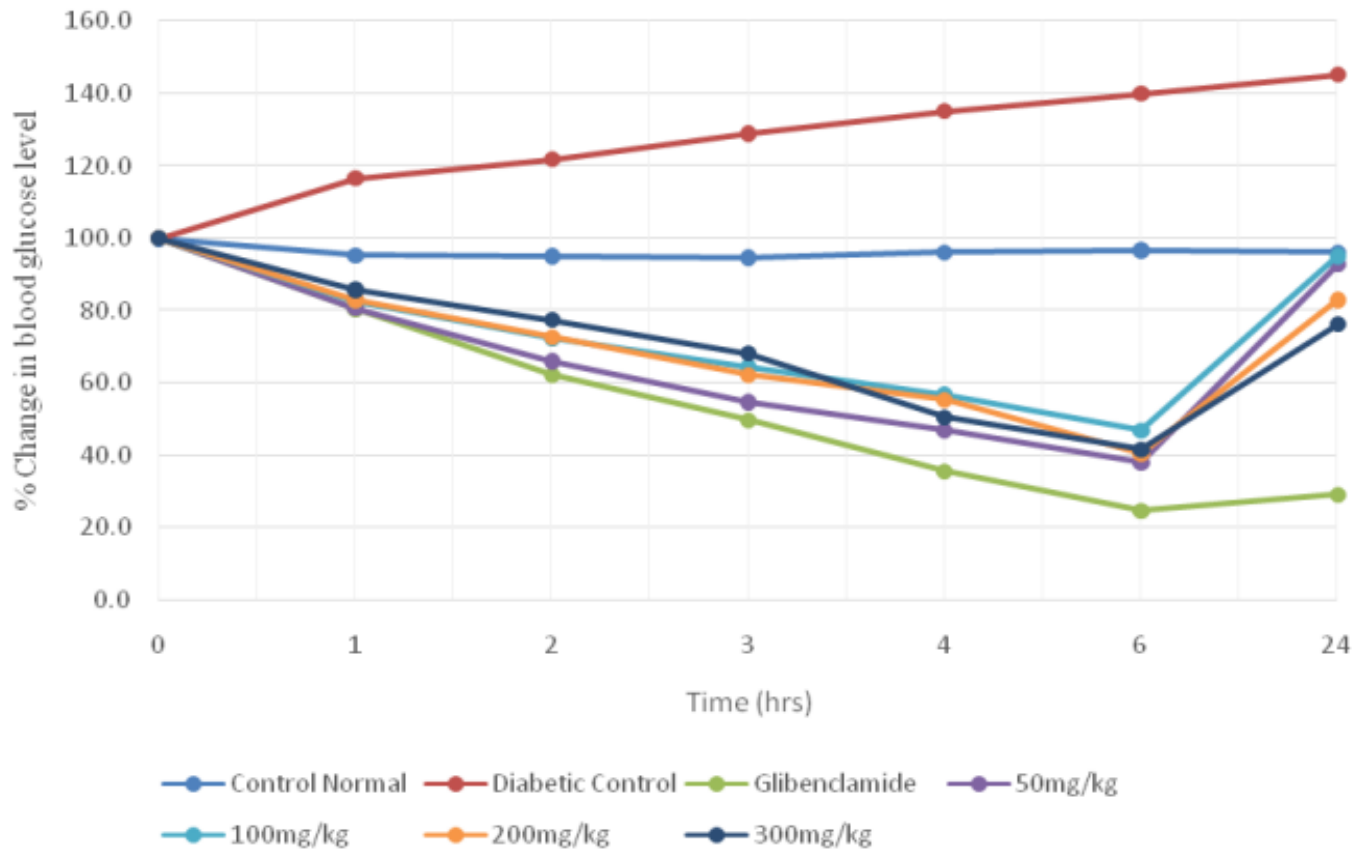

Figure 2: Mean percentage change in blood glucose levels of Acacia nilotica orally administered in alloxan induced diabetic mice.

\begin{tabular}{|c|c|}
\hline Phytochemicals Present & Quantity \\
\hline Phenols $\mathbf{( m g / g )}$ & 2.76 \\
\hline Alkaloids $(\mathbf{g} / \mathbf{1 0 0 g})$ & 1.86 \\
\hline Flavonoids $(\mathbf{m g} / \mathbf{g})$ & 0.29 \\
\hline Saponins $\mathbf{( g / 1 0 0 g )}$ & 9.36 \\
\hline Tannins $(\mathbf{m g} / \mathbf{g})$ & 2.06 \\
\hline Cardiac $\mathbf{g l y c o s i d e s}(\mathbf{m g} / \mathbf{g})$ & ND \\
\hline Phylobatannins $\mathbf{( m g / g )}$ & ND \\
\hline
\end{tabular}

Key: ND $=$ Not Detected

Table 3: Phytochemical composition of the aqueous leaf extracts of $A$. nilotica.

the oral route. Further, qualitative and quantitative phytochemical screening of aqueous leaf extracts of $A$. nilotica indicated the presence of phenols, alkaloids, flavonoids, tannins and saponins. However, cardiac glycosides and phylobatanins were not detected.

\section{References}

1. Bhowmik A, Liakot AK, Masfida A, Begum R (2009) Studies on the antidiabetic effects of Mangifera indica stem-barks and leaves on nondiabetic, type 1 and type 2 diabetic model rats. Bangladesh Journal of Pharmacology 4: 110-114.

2. Lunze K, Singh T, Walter M, Brendel DM, Leonhardt S (2013) Blood glucose control algorithms for type 1 diabetic patients; A methodological review. Biomedical Signal Processing and control 8: 107-119.

3. Tankoy Y, Mahdi M, Yaro AH, Musa KY, Mohamed A (2008) Hypoglycemic activity of methanolic stem bark of Adansonia digitata extract on blood glucose levels of streptozocin induced diabetic Winstar rats. International Journal of Applied Research in Natural Products 2: 32-36.

4. Agyare C, Asase A, Lechtenberg M, Niehues M, Deters A, et al. (2009) An ethnopharmacological survey and in vitro confirmation of ethnopharmacological use of medicinal plants used for wound healing in Bosomtwi-AtwimaKwanwoma area, Ghana. J Ethnopharmacol 125: 393-403.

5. WHO (2002) Traditional Medicine Strategy 2002-2005. World Health organization document.

6. Keter LK, Mutiso PC (2012) Ethnobotanical studies of medicinal plants used by Traditional Health Practitioners in the management of diabetes in Lower Eastern Province, Kenya. J Ethnopharmacol 139: 74-80.
7. Maundu PM, Ngugi GW, Kabuye CHS (1999) Traditional Food Plants of Kenya, Kenya resource centre for indigenous knowledge (KENRIK). National museums of Kenya, Nairobi, Kenya 43-44.

8. Bargali K, Bargali S (2009) Acacia nilotica: a multipurpose leguminous plant Nature and Science 7: 11.

9. Kumari M, Jain S, Dave R (2014) Babul (Acacia nilotica), A. potential source of tannin and its suitability in management of type II diabetes. Nutrition and food Science 44: 119-126.

10. Karau GM (2013) Biosprospecting of antidiabetic compounds from selected medicinal plants for the management of Diabetes Mellitus in Mbeere and Meru, Kenya, PhD Thesis 57

11. Rasool R, Ganai BA, Akbar S, Kamili AN, Masood A (2010) Phytochemical screening of Prunella vulgaris I. - an important medicinal plant of Kashmir. Pak J Pharm Sci 23: 399-402.

12. Mir AM, Sawhney SS, Jassal SMM (2013) Quantitative and qualitative analysis of phytochemicals of Taraxacum officinale. Wudpecker journal of pharmacy and pharmacology 2: 001-005.

13. Szkudelski $T$ (2001) The mechanism of alloxan and streptozotocin action in $B$ cells of the rat pancreas. Physiol Res 50: 537-546.

14. Ramaiah M, Ganga RB, Chakravarthi G (2013) Antidiabetic Activity of Methanolic Extract of Memecylon Malabaricum Cogn (Melastomataceae) Leaves. International Journal of Phytopharmacy 4: 822-828.

15. Rifat-uz-Z (2011) Glycaemic Evaluation of Folk Recipe (Medicinal Plants) in Alloxan Induced Diabetic Rabbits, British Journal of Medicine \& Medical Research 1: 67-84. 
Citation: Mukundi MJ, Piero NM, Mwaniki NEN, Murugi NJ, Daniel AS, et al. (2015) Antidiabetic Effects of Aqueous Leaf Extracts of Acacia nilotica in Alloxan Induced Diabetic Mice. J Diabetes Metab 6: 568. doi:10.4172/2155-6156.1000568

16. Ayodhya S, Kusum S, Anjali S (2010) Hypoglycaemic activity of different extracts of various herbal plants Singh. International Journal Ayurveda Resources Pharmaceutical 1: 212-224.

17. Mohammed RS, Hamideh MA, Sahraki R, Shafighi E (2013) Effect of Urtica dioica Decoction on Serum Glucose and Lipid Profile in Streptozoan Induced Diabetic Male rats. Zehdan journal of Research in Medicinal Sciences 15: 1518.

18. Elliot M, Chithan K, Theoharis CT (2000) The effects of plant flavanoids on mammalian cells: Implications for inflammation, heart disease and cancer. Pharmacol Rev 52: 673-751.

19. Li F, Li Q, Gao D, Peng Y (2009) The optimal extraction parameters and anti-diabetic activity of flavonoids from Ipomoea batatas leaf. Afr $\mathrm{J}$ Tradit Complement Altern Med 6: 195-202.
20. Modak M, Dixit P, Londhe J, Ghaskadbi S, Devasagayam TP (2007) Indian herbs and herbal drugs used for the treatment of diabetes. J Clin Biochem Nutr 40: 163-173.

21. Chauhan A, Sharma PK, Srivastava P, Kumar N, Duehe R (2010) Plants having potential antidiabetic activity: a review. Der Pharm Lett 2: 369-387.

22. Reher G, Slijepcevic M, Krans L (1991) Hypoglycemic activity of triterpenes and tannins from Sarcopoterium spinosum and two Sanguisorba Species. Planta Med 57: A57-A58.

23. Kako M, Miura T, Nishiyama Y, Ichimaru M, Moriyasu M, et al. (1997) Hypoglycemic activity of some triterpenoid glycosides. J Nat Prod 60: 604-605.

24. Kimura M, Suzuki J (1985) The pharmacological role of ginseng in the blend effect of traditional Chinese medicines in hyperglycemia. Advances of Chinese Medicinal Materials Research, World Scientific, Singapore. 